\title{
Nine generations of a family with autosomal dominant retinitis pigmentosa and evidence of variable expressivity from census records
}

\author{
M Jay, A C Bird, A N Moore, B Jay
}

\begin{abstract}
We present a nine generation family with autosomal dominant retinitis pigmentosa (ADRP). Evidence of blindness in the early generations, as obtained from census returns and clinical records, and examination of current patients show variable expressivity with a spectrum which ranges from asymptomatic in late life to blindness in the third decade of life. The family is not linked to any of the chromosomal locations so far described in ADRP and further illustrates the heterogeneity of the disorder.

( $f$ Med Genet 1992;29:906-10)
\end{abstract}

Retinitis pigmentosa (RP) comprises a group of disorders with an assessed prevalence in the UK of $1: 4869^{1}$ and is a common cause of blindness. It may be transmitted as an autosomal dominant, autosomal recessive, or $\mathrm{X}$ linked trait, and autosomal dominant RP (ADRP) is considered to be the mildest form of the disorder. ${ }^{2}$ However, Bundey and Crews ${ }^{1}$ found that $47 \%$ of their cases with ADRP were, or were expected to be, registered blind or partially sighted by the age of 40 years.

The clinical features of ADRP are characterised by a typical fundus appearance, narrowed retinal vessels, and changes in the electrophysiological responses of the eye. Early signs are night blindness and constriction of the visual fields with a variable age of onset. ${ }^{3}$ ADRP may be further subdivided into two groups based on electrophysiological and psychophysical testing. ${ }^{4}$ The two groups can be differentiated by the pattern of loss of rod function which is described as regional or diffuse. In type ' $R$ ' ADRP there is variation in age of onset of night blindness between and within families, patchy loss of rod and cone function, and the rod electroretinogram (ERG) may be only mildly affected. In type ' $D$ ', loss of rod function is diffuse and severe, and there is relative preservation of cone function in the earlier stages of the disease. The rod ERG is absent but there may be a detectable cone response. Night blindness is identified consistently within the first decade of life. The two types of ADRP seem to represent separate genetic entities since they have never been found in the same family.

Other variants of autosomal dominant retinitis pigmentosa have been identified. In some patients, slow recovery from a retinal bleach over as long as a few days has been recorded as an attribute of disease. ${ }^{5-7}$ Incomplete pene- trance is a characteristic of some other families. $^{8}$

We describe here a large family where subjects tested all have the ' $R$ ' phenotype and in which there is considerable variability of expression.

\section{Patients}

The nucleus families which comprise this pedigree were ascertained from a register of retinal dystrophies held at Moorfields Eye Hospital. The register contains details of patients seen at the Genetic Clinic and Electrodiagnostic Department of the hospital. It also contains limited information derived from a simple questionnaire sent to members of a support group, the British Retinitis Pigmentosa Society. The register is on computer, and it holds data of approximately 400 apparently unrelated families with ADRP. Only one nucleus family was ascertained from this questionnaire, and subjects from this family have since been examined in order to confirm the diagnosis of RP. Subjects are given a family number, and county of birth is indicated by a two digit code. ${ }^{9}$

\section{Methods}

Pedigrees of ADRP were inspected according to family surname and county of origin with the aim of tracing common ancestry. A number of three and four generation pedigrees were found originating from the region of St Albans and Watford in Hertfordshire. These pedigrees were extended by several generations using the resources of the Registrar General.

All births, marriages, and deaths recorded in England and Wales since 1837 are held by the Registrar General in indexes which are quarterly and alphabetical. These indexes may be consulted at the General Register Office in Kingsway, London. All certificates in England and Wales have to be purchased, whereas in Scotland they may be inspected free of charge. The dates when registration began in Scotland are somewhat different, and the methods of tracing ancestry there have been described by Collyer and DeMey. ${ }^{10}$ Scotland, Northern Ireland, the Irish Republic, the Isle of Man, the Scilly Isles, and the Channel Islands each have their own system of registration. The Public Record Office (Chancery Lane, London WC2 1LR) produces a number of leaflets giving information as to genealogical sources and where they are held. 
The birth certificates give the name of the child, the name and occupation of the father, the name and maiden name of the mother, and the address of the parents. Marriage certificates give the surname, Christian name, occupation, and address of both parties, also the name and occupation of the father of each party. Death certificates give full name, address, age, cause of death, and the name of the person reporting the death.

The index entries of births since 1911 give the mother's maiden name, and those of marriages since 1911 give a cross reference to the surname of the other party. Each entry gives a registration district where the event took place and this entry bears a number, so that it is simple to identify both parties of a marriage occurring after 1911, and it is possible but more laborious to do the same for marriages before 1911. This limits the number of certificates which may be needed, and reduces the cost which may be considerable when researching a large family. The constraints however are those which apply to all genealogy, and these are that the event has to be registered, and that the surname is not a common one. This is particularly true in Wales where a few surnames are shared by a large proportion of the population. An excellent account of genealogical sources in Wales has been given by Moore. ${ }^{11}$

Ultimately, a relevant entry will be found of a birth in the period covered by the census, and the certificate must be purchased in order to find the address or the rural parish. The decennial censuses from 1841 to 1891 are recorded on microfilm and are available for inspection by the public at the Public Record Office and in local County Record Offices. Each census is ordered according to parish, so that an address is essential. From 1851, the census entries include a disability column and also the parish of birth so that existing parish registers which are held in County Record Offices may then be searched. The Society of Genealogists in London also has copies of the registers of more than 700 parishes as well as a unique collection of surname indexes, and trade and professional directories.

Limited use was made of the International Genealogical Index, a microfiche produced by the Church of the Latter Day Saints. Coverage of countries in the $\mathrm{UK}$ is variable, and while almost complete for the City of London before 1837 , it is non-existent for some counties such as Huntingdon. The original parish registers were inspected in order to verify entries as handwriting is a common source of error, and also entries have been sometimes overlooked in transcribing.

Clinical details of index patients and of some of their affected relatives were obtained from hospital notes at Moorfields Eye Hospital. Details of other relatives who were not examined were obtained by telephone interview.

\section{Results}

The pedigree of the family is shown in fig 1 . All persons in the first five generations are dead. Details of census entries relating to persons in the early generations are given in table

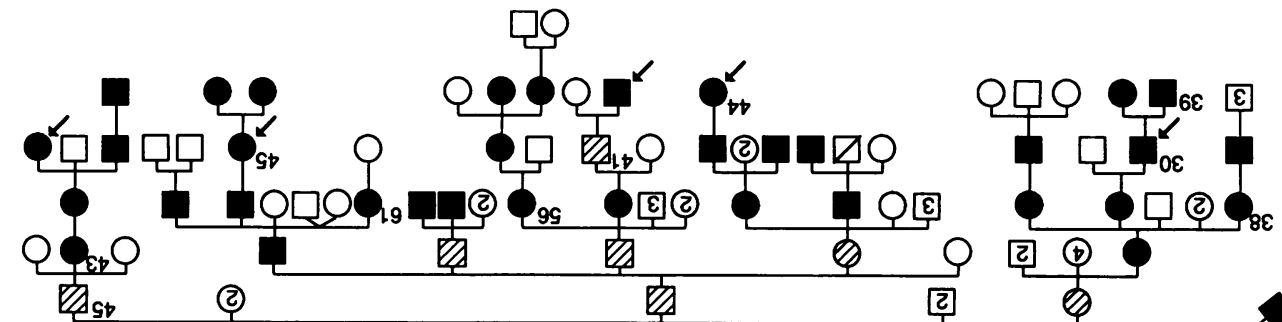

宛

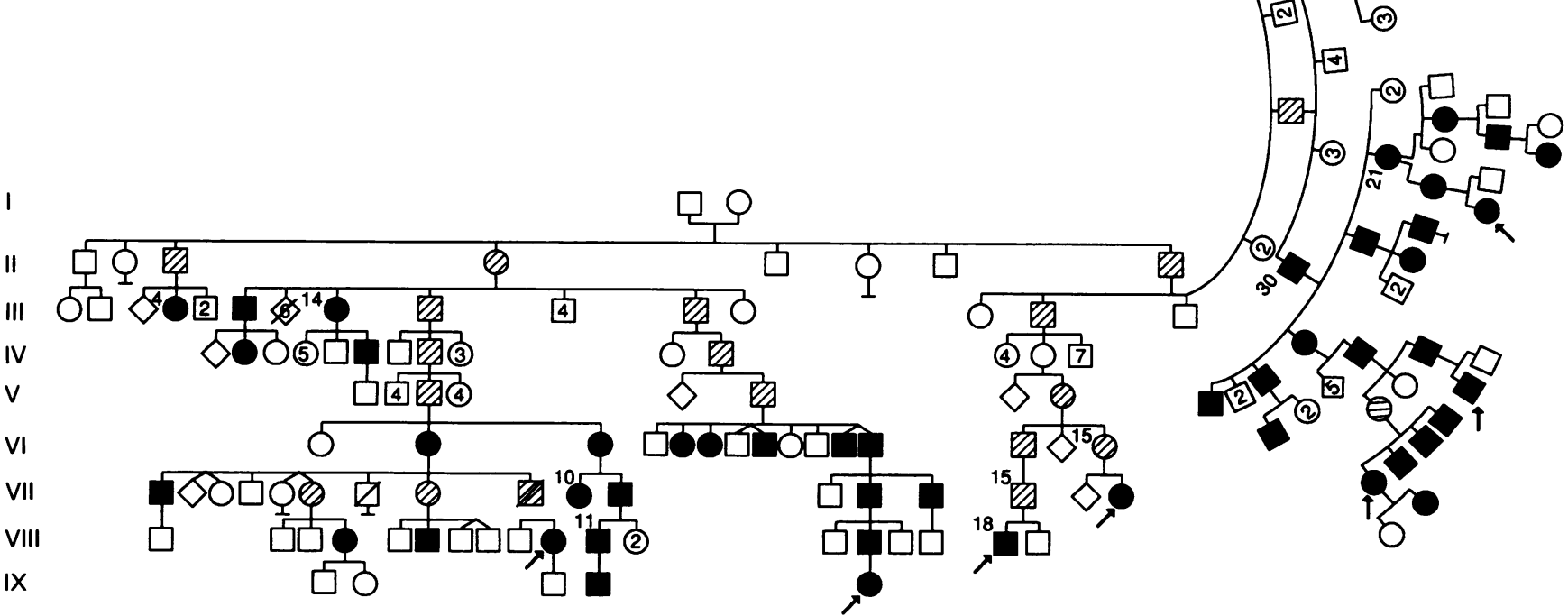

Figure 1 Family $N$ with autosomal dominant RP. The solid symbols indicate those subjects known to be affected from history or from census records. The hatched symbols indicate subjects presumed affected. The probands are shown by an arrow. 
Table 1 Census entries of subjects in generations III and $I V$.

\begin{tabular}{llll}
\hline III.4 JN & Blind age 61 1851 HO107 & $1713 \mathrm{f} .193 \mathrm{p} 14$ \\
III.7 JK & Blind age 72 1851 HO107 & $1714 \mathrm{f} .219 \mathrm{p} 17$ \\
III.14 EN & Blind age 68 1851 HO107 & $1713 \mathrm{f} .583 \mathrm{p} 15$ \\
IV.2 AK & Blind age 42 1851 HO107 & $1714 \mathrm{f} .219 \mathrm{p} 17$ \\
IV.10 TN & Blind age 28 1851 HO107 & $1713 \mathrm{f} .510 \mathrm{p} 4$ \\
IV.30 WN & Blind age 50 1881 RG11 & $1483 \mathrm{f.127}$ p12 \\
\hline
\end{tabular}

1 , and an example of a census entry is illustrated in fig 2. The age of onset of symptoms and visual outcome of the 13 index patients and a further affected 60 relatives are given in table 2 .

The visual status of John Norwood (I.1) can be inferred from his will which was signed by him and dated 11 March 1785 when he was 60 years old. Blind persons had their will read out to them in the presence of witnesses; such wills were unsigned, are termed nuncupative, and were legal until $1837 .{ }^{12}$ Nuncupative wills were also used in cases where the testator was physically debarred from signing, and a number of these wills may be found from the time of the Great Plague in 1665.

The examples of blindness as reported in census returns are surprising. Disabilities tended to be underreported because of suspicion of officialdom and fear of the workhouse. Several subjects from this family had affected descendants but did not describe themselves as blind, and it must be concluded that they were only mildly affected or that they may have died young. One subject, however, IV.10, was described as blind at the age of 28 in the census of 1851 , and 'blind since 10 years' in the census of 1861. Some information may be derived from the occupation recorded in the census, for example the occupation of III.7, aged 72 and blind, was given as a labourer in the maltings. While no details are given as to the nature of his work, it is likely that he had enough central vision to enable him to load beer barrels. His daughter, IV.2, was a shop keeper in the 1851 census, but 10 years later at the age of 52 had an annuity from the local Blind Society and presumably was no longer able to work. III.45 was aged 27 in 1881 and there is no indication that he was affected; his affected granddaughter remembers him as being unaffected. While census entries were found for the majority of gene carriers in generations III and IV, these were not necessarily informative, as subjects were frequently too young at the time of a census. The word 'blind' is used in census entries to describe a disability, and it is no more than a pointer indicating which family members could have been severely affected. Clinical data are available for subjects from generation IV onwards and, in particular, age of onset.

Affected subjects in this family have the ' $R$ ' type of ADRP which has a variable age of onset of symptoms, and $23 / 41$ cases $(56 \%)$ had an onset in the second decade of life, while six experienced symptoms before the age of 10 , and the remainder had visual difficulties at ages varying from 21 to over 50 years. There is similar variability in the progression of the disorder with the largest group being mildly affected. In this group are included 11 who were considered blind in their $60 \mathrm{~s}$ but who retained enough central vision to read. At the two extremes are the group of 13 who were asymptomatic or unaffected on examination despite being gene carriers, and the severely affected group of 13 who included those blind in their 20s and 30s. The remaining group of 11 became blind in their $40 \mathrm{~s}$ and $50 \mathrm{~s}$ and complete a spectrum of clinical expression which varies from asymptomatic to blind in the third decade.

Age of onset of symptoms is known in 41 subjects and distribution of cases according to age of onset is given in table 3 . The severity of

17

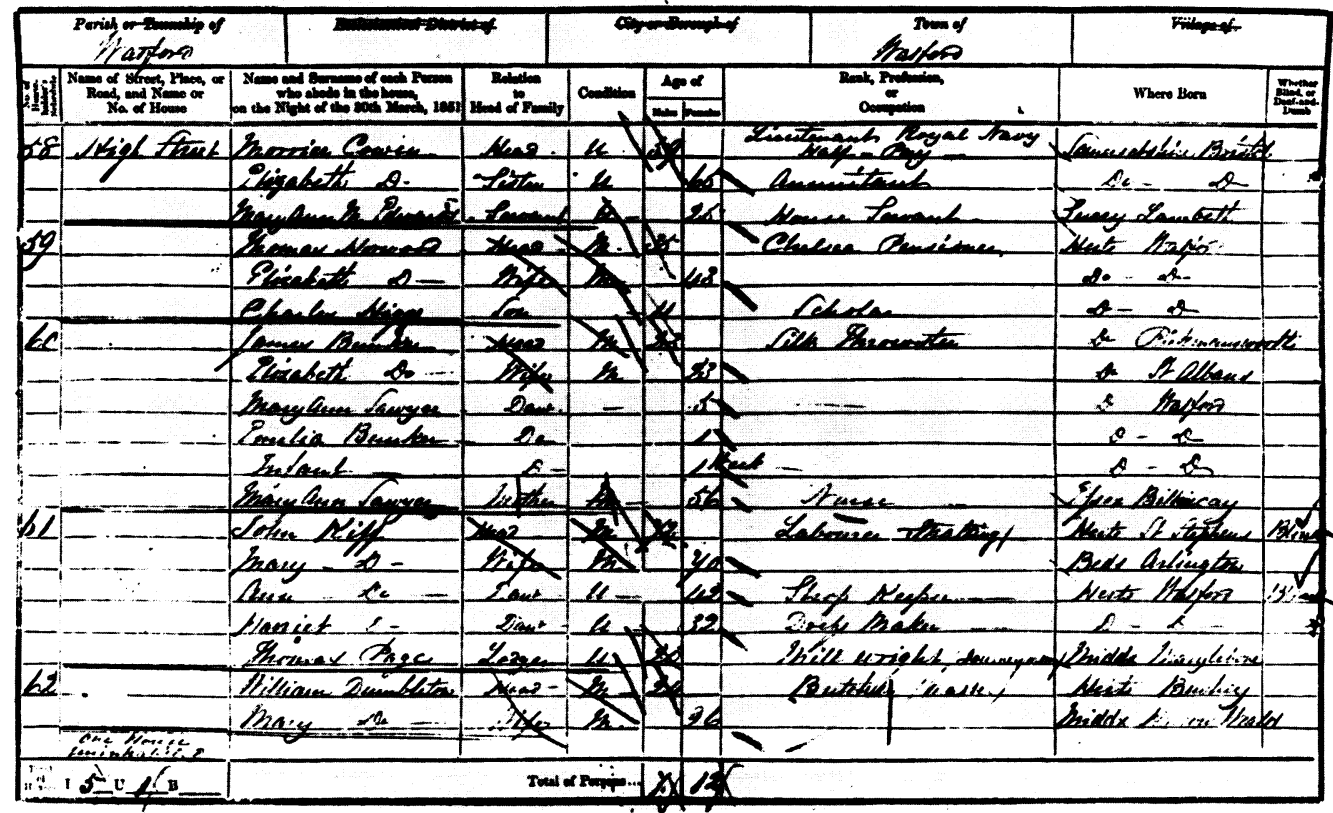

Figure 2 Entry from the census of 1851 (PRO reference HO107 1714 f.219 p17). The right hand column shows that father and daughter were blind. (Crown copyright, reproduced with permission of the Controller of Her Majesty's Stationery Office.) 
Table 2 Age of onset and visual outcome in 73 family members with abnormal genotype.

\begin{tabular}{|c|c|}
\hline $\begin{array}{l}\text { III.4 } \\
\text { III.7 } \\
\text { III.14 }\end{array}$ & $\begin{array}{l}\text { Blind at } 61 \\
\text { Blind at } 72 \\
\text { Blind at } 68\end{array}$ \\
\hline $\begin{array}{l}\text { IV. } 2 \\
\text { IV.10 } \\
\text { IV. } 30 \\
\text { IV. }\end{array}$ & $\begin{array}{l}\text { Blind at } 42 \\
\text { Blind at } 28 \\
\text { Blind at } 50 \\
\text { Asymptomatic }\end{array}$ \\
\hline $\begin{array}{l}\text { V.21 } \\
\text { V.27-29 } \\
\text { V.43 }\end{array}$ & $\begin{array}{l}\text { Blind in } 60 \mathrm{~s} \\
\text { Blind in } 60 \mathrm{~s} \\
\text { Onset at } 12 \text {, blind in } 60 \mathrm{~s}\end{array}$ \\
\hline $\begin{array}{l}\text { VI. } \\
\text { VI. } \\
\text { VI. } \\
\text { VI. } \\
\text { VI. } \\
\text { VI. } \\
\text { VI.42 } \\
\text { VI.43 } \\
\text { VI.55 } \\
\text { VI. } 56 \\
\text { VI. } 61 \\
\text { VII.65 } \\
\text { VI. } 67\end{array}$ & $\begin{array}{l}\text { Blind in early } 40 \text { s } \\
\text { Onset (field loss) in } 60 \mathrm{~s} \\
\text { Asymptomatic aged } 83 \\
\text { Blind at } 29 \\
\text { Blind at } 49 \\
\text { Blind in } 60 \mathrm{~s} \\
\text { Blind at } 60 \text {, can read at } 83 \\
\text { Mildly affected at } 70 \\
\text { Onset at } 15 \text {, blind at } 40 \\
\text { Onset at } 15 \text {, blind at } 40 \\
\text { Onset at } 28 \text {, blind } 60 \text { s, could read at } 75 \\
\text { Onset (field loss) in } 50 \text { s, blind } 60 \text { s, can read at } 75\end{array}$ \\
\hline $\begin{array}{l}\text { VII.1 } \\
\text { VII.6 } \\
\text { VII.8 } \\
\text { VII.9 } \\
\text { VII.10 } \\
\text { VII.11 } \\
\text { VII.13 } \\
\text { VII.14 } \\
\text { VII.15 } \\
\text { VII.17 } \\
\text { VII.18 } \\
\text { VII.20 } \\
\text { VII.21 } \\
\text { VII.23 } \\
\text { VII.25 } \\
\text { VII.26 } \\
\text { VII.27 } \\
\text { VII.28 } \\
\text { VII.29 } \\
\text { VII.30 } \\
\text { VII.41 }\end{array}$ & $\begin{array}{l}\text { Onset (field loss) at } 18 \text {, blind } 60 \text { s, can read at } 69 \\
\text { Asymptomatic, suspicious fundi at } 61 \\
\text { Not affected at } 60 \text {, has glaucoma } \\
\text { Asymptomatic at } 56 \\
\text { Onset (night blindness) at } 27 \text {, blind in } 40 \text { s } \\
\text { Sees to work at } 62 \text {, mild disease } \\
\text { Mild at } 50 \\
\text { Mild at } 48 \\
\text { Asymptomatic at } 60 \\
\text { Blind at } 55 \\
\text { Not affected (on examination) at } 65 \\
\text { Onset at } 14 \text {, blind at } 38 \\
\text { Onset at } 12 \text {, blind at } 20 \\
\text { Onset at } 5 \text {, severely affected at } 27 \\
\text { Severely affected from } 30 \text {, blind } 50 \\
\text { Onset (fields) at } 56 \\
\text { Onset } 18 \text {, severely affected in } 50 \text { s } \\
\text { Onset late teens, mildly affected at } 44 \\
\text { Onset (fields) at } 26 \text {, blind in } 60 \text { s } \\
\text { Onset in childhood (age } 5-9 \text { ), blind at } 32 \\
\text { Asymptomatic, minimal recordable abnormality of } \\
\text { night vision at } 40\end{array}$ \\
\hline $\begin{array}{l}\text { VII.43 } \\
\text { VII.45 } \\
\text { VII.48 } \\
\text { VII.50 }\end{array}$ & $\begin{array}{l}\text { Blind in early } 40 \text { s } \\
\text { Onset (night blindness) at } 15 \text {, mildly affected at } 45 \\
\text { Onset at } 18 \text {, severely affected at } 45 \\
\text { Onset at } 18, \text { mildly affected }\end{array}$ \\
\hline $\begin{array}{l}\text { VIII.4 } \\
\text { VIII.6 } \\
\text { VIII.10 } \\
\text { VIII.11 } \\
\text { VIII.15 } \\
\text { VIII.18 } \\
\text { VIII.20 } \\
\text { VIII.21 } \\
\text { VIII.22 } \\
\text { VIII.23 } \\
\text { VIII.24 } \\
\text { VIII.26 } \\
\text { VIII.28 } \\
\text { VIII.29 } \\
\text { VIII.39 } \\
\text { VIII.40 } \\
\text { VIII.44 } \\
\text { VIII.45 } \\
\text { VIII.47 } \\
\text { VIII.48 } \\
\text { VIII.50 } \\
\text { VIII.51 } \\
\text { VIII.52 }\end{array}$ & $\begin{array}{l}\text { Onset (night blindness) at } 30 \text {, mildly affected } \\
\text { Onset (fields) at } 7 \text {, severely affected in } 20 \text { s } \\
\text { Onset (night blindness) at } 5 \text {, blind at } 41 \\
\text { Early peripheral changes at } 5 \cdot 5 \text { years, mildly affected } \\
\text { Mildly affected at } 37 \\
\text { Onset at } 18 \text {, severely affected at } 26 \\
\text { Diagnosed in mid-30s, asymptomatic } \\
\text { Asymptomatic } \\
\text { Asymptomatic } \\
\text { Asymptomatic } \\
\text { Onset at } 16 \text {, severely affected at } 32 \\
\text { Onset at } 13 \\
\text { Onset at } 16 \\
\text { Onset at } 19 \text {, mildly affected at } 22 \\
\text { Onset (night blindness) at } 24 \\
\text { Onset (night blindness) at } 16 \\
\text { Asymptomatic, mild PE changes at } 19 \\
\text { Onset (night blindness) at } 8 \text {, severely affected at } 25 \\
\text { Onset late teens, blind at } 33 \\
\text { Severely affected at } 31 \\
\text { Onset (night blindness) at } 15 \text {, mildly affected at } 22 \\
\text { Onset (night blindness) at } 15 \text {, mildly affected at } 24 \\
\text { Onset (night blindness) at } 15\end{array}$ \\
\hline $\begin{array}{l}\text { IX.4 } \\
\text { IX.5 } \\
\text { IX.7 }\end{array}$ & $\begin{array}{l}\text { Onset at } 11 \\
\text { Fundus not RP, symptoms at } 3 \text {, goes to blind school } \\
\text { Onset at } 14\end{array}$ \\
\hline
\end{tabular}

the disorder is known in 73 cases from generation IV onwards, and the distribution of these 73 cases is given in table 4; it cannot be determined in a further seven as they are too young. Psychophysical testing of subjects VII.41, VIII.10, VIII.28, VIII.29, and VIII.45 showed a pattern of regional loss of rod function.

\section{Discussion}

The common ancestry of the families which comprise this pedigree was relatively easy to trace. Owing to the numerous instances of male to male transmission, the study of the first four generations was virtually that of two surnames. Except for London, these two surnames were restricted to a few neighbouring parishes in Hertfordshire and this limited the search of parish registers. In addition, it was possible to situate the blind subjects found in census records within the family, either by tracing the ancestry of the 13 probands, or by finding the descendants of I.1 quoted in his will. Surnames are valuable genetic markers provided that they are not common, and first names often follow a pattern with the children being named after one or other parent, grandparent, and other relatives. Surnames also show geographical clustering, particularly before the time of the Industrial Revolution which led to migration of rural population. This family is unusual in that the majority still live in the same area as their ancestors.

A number of mutations have been found in rhodopsin, the rod visual pigment gene, in a proportion of cases with ADRP. The first of these mutations, a cytosine to adenine transversion was found in codon 23 of rhodopsin by Dryja et al. ${ }^{13}$ Subsequently other mutations in rhodopsin have been found, as well as linkage to a chromosome $8 \mathrm{p}$ marker PLAT, ${ }^{14}$ and mutations in the human peripherin/rds gene. ${ }^{1516}$ Of the 33 mutations which have been found in families from the USA, the UK, and Europe, the majority appear to be unique to each family. ${ }^{17-19}$ Exceptions exist illustrated by the codon 347 mutation which has been found in disparate communities, and which has been identified as a new mutation suggesting a mutational hotspot. ${ }^{2021}$ Although the codon 23 mutation in rhodopsin has been found in 17 out of 148 unrelated subjects with ADRP in the USA, linkage disequilibrium suggesting a common ancestry, and since the codon 23 mutation has not been found in any UK or other European family so far, it is probable that the mutation was carried by an early immigrant from the Old World to the New. ${ }^{22}$ The different mutations on the rhodopsin gene

Table 3 Distribution of cases according to age of onset of symptoms.

\begin{tabular}{lr}
\hline Age group & No \\
\hline $5-9$ & 6 \\
$10-14$ & 5 \\
$15-20$ & 18 \\
$21-30$ & 5 \\
$31-40$ & 4 \\
50 and over & 3 \\
Total & 41 \\
\hline
\end{tabular}

Table 4 Distribution of cases according to severity of disorder.

\begin{tabular}{llll}
\hline $\begin{array}{l}\text { Asymptomatic or unaffected on } \\
\text { examination }\end{array}$ & 13 & $(20 \cdot 6 \%)$ \\
$\begin{array}{l}\text { Mildly affected/independently mobile } \\
\text { until } 60\end{array}$ & 26 & $(41 \cdot 3 \%)$ \\
$\begin{array}{l}\text { Severely affected/blind by } 40 \\
\text { Blind in 40s and 50s }\end{array}$ & 13 & $(20 \cdot 6 \%)$ \\
\hline
\end{tabular}


appear to give rise to differences both in the severity and distribution of the visual loss..$^{23-29}$

It would appear that the family we have described with variable expressivity shown by archival material is yet another example of the heterogeneity of autosomal dominant retinitis pigmentosa. This family has been sampled for DNA linkage and, to date, no linkage or DNA mutations have been found to these chromosomal sites ( $\mathrm{S}$ Bhattacharya, personal communication). The identification of new loci at which mutations may cause RP is dependent upon large families such as this, and the use of archival sources is crucial to the generation of these pedigrees. It is particularly encouraging that it is also possible to gain some indication of the subtype of RP from recorded disability in members of generations in the last century.

We are grateful for the support of the National Retinitis Pigmentosa Foundation Fighting Blindness USA and the British Reginitis Pigmentosa Society for funding this research. We would like to thank the Public Record Office for permission to reproduce the census entry, and the staff of the Hertfordshire County Record Office for their assistance.

1 Bundey S, Crews SJ. A study of retinitis pigmentosa in the city of Birmingham. II. Clinical and genetic heterogen eity. I Med Genet 1984;21:421-8.

2 Merin S, Auerbach E. Retinitis pigmentosa. Surv Ophthalmol 1976;20:303-46.

3 Pagon RA. Retinitis pigmentosa. Surv Ophthalmo 1988;33:137-77.

4 Lyness AL, Ernst W, Quinlan MP, et al. A clinical, psychophysical, and electroretinographic survey of patients with autosomal dominant retinitis pigmentosa. $B r \mathcal{F}$ Ophthalmol 1985;69:326-39.

5 Alexander KR, Fishman GA. Prolonged dark adaptation in retinitis pigmentosa. Br $\mathcal{f}$ Ophthalmol 1984;68:561-9.

6 Ernst W, Moore AT. Heterogeneity, anomalous adaptation and incomplete penetrance in autosomal dominant retinitis pigmentosa. In: Zrenner E, Krastel H, Goebel HH, tis pigmentosa. In: Zrenner E, Krastel $\mathrm{H}$, Goebel HH, eds. Research in retin

7 Ernst W, Kemp CM, Moore AT. Abnormal dark adaptation in autosomal dominant retinitis pigmentosa (AD RP). Invest Ophthalmol Vis Sci (Suppl) 1987;28:236.

8 Berson EL, Gouras P, Gunkel RD, Myrianthopoulus NC. Dominant retinitis pigmentosa with reduced penetrance. Arch Ophthalmol 1969;81:226-35.

9 Jay $M$. On the heredity of retinitis pigmentosa. $\mathrm{Br} \mathcal{F}$ Ophthalmol 1982;66:405-16.

10 Collyer S, DeMey R. Public records and recognition of genetic disease in Scotland. Clin Genet 1987:31:125-31.
11 Moore P. Parish Registers and Sources for Genealogical Studies in Wales. In: Harper PS, Sunderland E, eds. Genetic and population studies in Wales. Cardiff: University of Wales Press, 1986:251-69.

12 Camp AJ. Wills and their whereabouts. London: A J Camp, 1974:xiii.

13 Dryja TP, McGee T, Reichel E, et al. A point mutation of the rhodopsin gene in one form of retinitis pigmentosa. Nature 1990;343:364-6.

14 Blanton SH, Heckenlively JR, Cottingham AW, et al. Linkage mapping of autosomal dominant retinitis pigmentosa (RP1) to the pericentric region of human chromosome 8. Genomics 1991;11:857-69.

15 Farrar GJ, Kenna P, Jordan S, et al. A three base pair deletion in the peripherin-rds gene in one form of retinitis pigmentosa. Nature 1991;354:478-80.

16 Kajiwara K, Hahn LB, Mukai S, Travis GH, Berson EL, Dryja TP. Mutations in the human retinal degeneration slow gene (rds) in autosomal dominant retinitis pigmentosa. Nature 1991;354:480-3.

17 Sung $\mathrm{CH}$, Davenport CM, Hennessey JC, et al. Rhodopsin mutations in autosomal dominant retinitis pigmentosa. Proc Natl Acad Sci USA 1991;88:6481-5.

18 Dryia TP, Hahn LB, Cowley GS, McGee TL, Berson EL. Mutation spectrum of the rhodopsin gene among patients with autosomal dominant retinitis pigmentosa. Proc Natl Acad Sci USA 1991;88:9970-4.

19 Inglehearn CF, Keen TJ, Bashir R, et al. A completed screen for mutations of the rhodopsin gene in a panel of patients with autosomal dominant retinitis pigmentosa. Hum Mol Genet 1992;1:41-5.

20 Dryja TP, McGee TL, Hahn LB, et al. Mutations within the rhodopsin gene in patients with autosomal dominan retinitis pigmentosa. $N$ Engl f Med 1990;323:1302-7.

21 Fujiki K, Hotta Y, Shiono T, et al. Codon 347 mutation of the rhodopsin gene in a Japanese family with autosomal dominant retinitis pigmentosa. Invest Ophthalmol Vis $\mathrm{SCi}$ 1991;32(suppl): 1137

22 Dryja TP. The Doyne Lecture. Rhodopsin and autosomal dominant retinitis pigmentosa. Eye 1992;6:1-10.

23 Heckenlively JR, Rodrigues JA, Daiger SP. Autosomal dominant sectoral retinitis pigmentosa, two families with transversion mutation in codon 23 of rhodopsin. Arch Ophthalmol 1991;109:84-91.

24 Berson EL, Rosner B, Sandberg MA, Dryja TP. Ocular findings in patients with autosomal dominant retinitis pigmentosa and rhodopsin gene defect. Arch Ophthalmo 1991;109:92-101.

25 Weleber RG, Murphey WH, Rodrigues JA, Lovrien EW, Litt M, Daiger SP. Phenotypic expression of the Pro23His mutation of rhodopsin in a large family with autosomal dominant retinitis pigmentosa. Invest Ophthalmol Vis Sci Suppl 1991;32:913.

26 Fishman GA, Stone EM, Gilbert LD, Kenna P, Sheffield VC. Ocular findings associated with a rhodopsin gene transversion mutation in autosomal dominant retinitis pigmentosa. Arch Ophthalmol 1991;109:1387-93.

27 Migm AT, Fitzke FW, Kemp CM, et al. Abnormal dark adaptation kinetics in autosomal dominant sector retinitis pigmentosa due to rod opsin mutation. $\mathrm{Br} \mathcal{F}$ Ophthalmol pigmentosa due

28 Jacobson SG, Kemp CM, Sung CH, Nathans J. Retinal function and rhodopsin levels in autosomal dominant retinitis pigmentosa with rhodopsin mutations. Am $\mathfrak{F}$ Ophthalmol 1991;112:256-71.

29 Kemp CM, Jacobson SG, Roman AJ, Sung CH, Nathans J. Abnormal rod adaptation in autosomal dominant retinitis pigmentosa with Pro-23-His rhodopsin mutation. $\mathrm{Am} \mathfrak{F}$ Ophthalmol 1992;113:165-74. 